\title{
Track-quality index and degradation of railway track structure: The construction track doubling project of northeast line from thanon chira junction to khon kaen station, Thailand
}

\author{
Thawatchai Phanyakit ${ }^{1{ }^{*}}$ and Thaned Satiennam ${ }^{2}$ \\ ${ }^{1}$ Department of Civil Engineering, Faculty of Engineering, Khon Kaen University, Khon Kaen, 40002, Thailand \\ ${ }^{2}$ Department of Civil Engineering, Faculty of Engineering, Khon Kaen University, Khon Kaen, 40002, Thailand
}

\begin{abstract}
In the past, the railway network has not been developed, and new construction added has been mostly degraded caused by long useful life, and lack of maintenance due to a budget constraint. Currently, $93 \%$ of railway in Thailand is single track which results in delays due to low capacity and low average speeds, delayed train on a single track will also delay the train passing it. In some areas of the network, the amount of travel and transportation exceeds the capacity received, so delays in travel and transportation is quite high. Due to this above reason, the service of railway is not effective in terms of convenience and speed of service. Punctuality and cost is high compared with road transport. The biggest challenge that railways faces is the insufficient number of tracks and outdated or old trains. Most the trains cannot travel at their optimum speed because they do not get clearances on time. Thai government has a policy to develop railway track network and services to improve transportation efficiency and save fuel energy used in the transportation sector of the country. Thus, it is necessary to develop the rail transportation system from the existing network as a single track to the current double track network. This study focuses on investigating the degradation of the existing railway structure during the construction track doubling Project. Data were inspected by Track Inspection Car EM120N before the commencement of construction for analysing the condition with the Track Quality Index / TQI) in order to predict the degradation of the railway to plan maintenance and further renewal of the railway. The study found that the TQI value of the existing track structure during the two years of the doubling track construction (2017-2018) has changed significantly.
\end{abstract}

\section{Introduction}

\subsection{Railway track structure}

Railway track structure can be divided into two main parts i.e. superstructure and substructure. The superstructure consists of rails, fastening system, rail pads, and sleepers. The substructure consists of ballast, sub-ballast, and subgrade. Figure 1 shows track design and elements of ballast track structure.

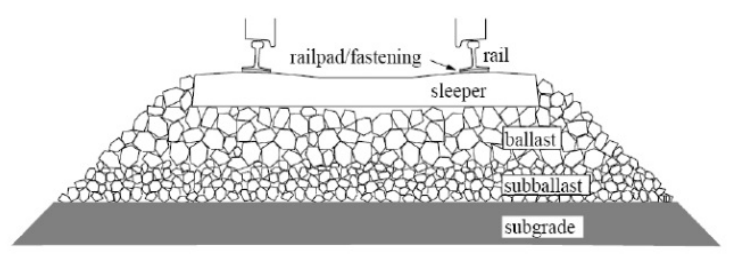

Fig. 1. Track design of a ballasted track. [Dahlberg, 2003]

\subsection{Track quality index definition}

TQI refers to figures of merit that objectively quantify the condition of the track. The index is computed from data collected by Track Inspection Car (TIC). Track geometry parameters consist of gage, cross level, longitudinal level, alignment, and twist. TQI is a statistical summary of a track geometry parameter measured over a prescribed length of track and effectively summarized a large number of measurements of each parameter for a given track segment.

\subsection{Track Inspection car (TIC)}

In prior maintenance works, the measurement of the track geometry parameters is normally carried out within a specific time interval. The results are recorded as numerical values, which can be used to indicate the level of track quality. In Thailand, track condition monitoring for Railway Track has inspected by the Track Inspection Car (EM120N) (Figure2\&3).

\footnotetext{
* Corresponding author: thawatchai.enkku@gmail.com
} 


\subsection{Track irregularity measurement}

Development of track degradation model has mentioned to the use of track geometry or shape data to classify the track geometry irregularities. Calculation of Track Quality Index (TQI) has been specifically developed to be more flexible to application to the degradation of parameters and to become more efficient and optimal to indication or description of various behaviors correctly. Some track parameters are identified as "track geometry" or track shape. The design of geometry usually has specific criteria to assure the safety and convenience in train operation. The standard of State Railway of Thailand (SRT) has specified the criteria of track irregularities required to be measured the deviation in following five types:

- Track gauge

- Cross level

- Longitudinal level

- Alignment

\subsection{Track quality index tolerance}

Track quality index tolerance is track irregularity index or acceptable track condition index. SRT defined the index properly with track maintenance work at present by considering significantly in terms of competency, economy, and riding comfort. The track quality Index tolerance is divided into 5 types, and each consists of index in each deviation list as follows:

Table 1. SRT standard TQI tolerance. [SRT, 2017]

\begin{tabular}{|c|c|c|c|c|c|c|}
\hline \multirow[b]{2}{*}{$\begin{array}{c}\text { Track } \\
\text { Qualit } \\
\text { y } \\
\text { Condi } \\
\text { tion }\end{array}$} & \multicolumn{5}{|c|}{ P Value or TQI Value each Item (\%) } & \multirow{2}{*}{ 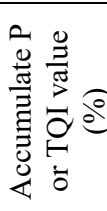 } \\
\hline & 胥 & 竞 & 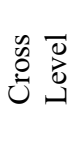 & 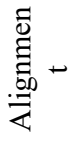 & $\frac{\vec{n}}{3}$ & \\
\hline $\begin{array}{l}\text { Very } \\
\text { Good }\end{array}$ & A & $0-13$ & $0-5$ & $0-9$ & $0-14$ & $0-10$ \\
\hline Good & B & $14-20$ & $6-13$ & $10-20$ & $15-27$ & $11-20$ \\
\hline Fair & $\mathrm{C}$ & $21-30$ & $14-22$ & $21-31$ & $28-36$ & $21-30$ \\
\hline $\begin{array}{l}\text { Not } \\
\text { Fair }\end{array}$ & D & $31-40$ & 23-31 & $32-41$ & $37-46$ & $31-40$ \\
\hline $\begin{array}{c}\text { Not } \\
\text { Accep } \\
\text { tance }\end{array}$ & $\mathrm{E}$ & $>41$ & $>32$ & $>42$ & $>47$ & $>41$ \\
\hline
\end{tabular}

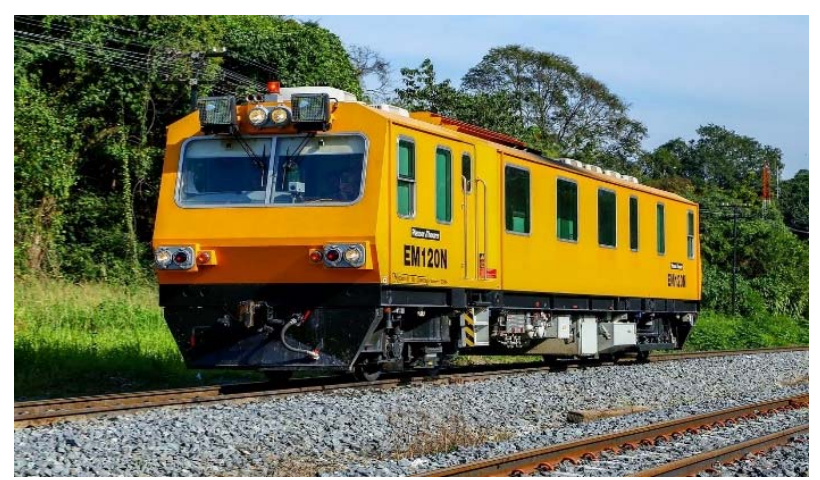

Fig. 2. Track inspection car [EM120N] .(SRT, 2015)

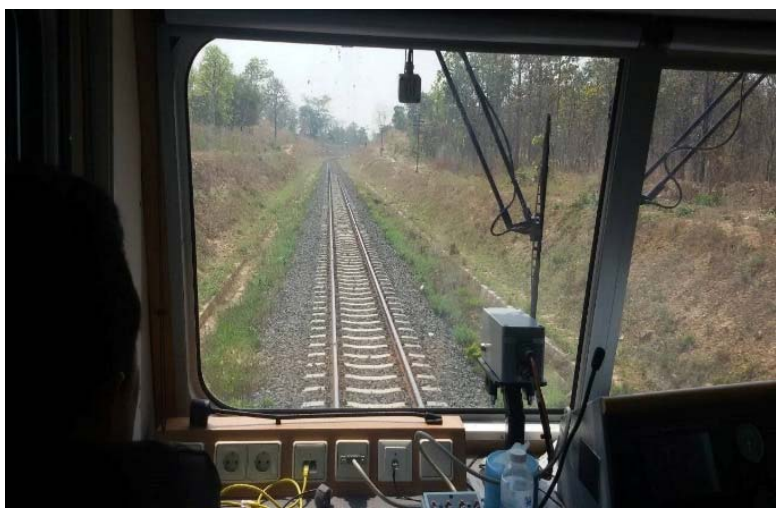

Fig. 3. Monitoring TQI by EM 120N. [SRT, 2018]

\subsection{Basics of factors influencing degradation}

The ability to forecast geometry degradation is very necessary for deciding when maintenance and renewal $(M \& R)$ are required. In addition, the same train intervals may have a degradation rate, so it is necessary to gather geometry data to find the ideal value for most of the maintenance and improvement. To identify the influencing factors, the degradation of the quality index will be calculated for both the millimeter/MGT traffic and the millimeter/year if there is no subsidence and rapid degradation of the railway after the tamping. This paper presents about the factors influencing the construction of the double track railway at Thanon Chira Junction to Khon Kaen Station. However, to see the degradation of the railway structure in overview from the literature review, additional factors arising from the double rail construction are also presented as shown in figure 4.

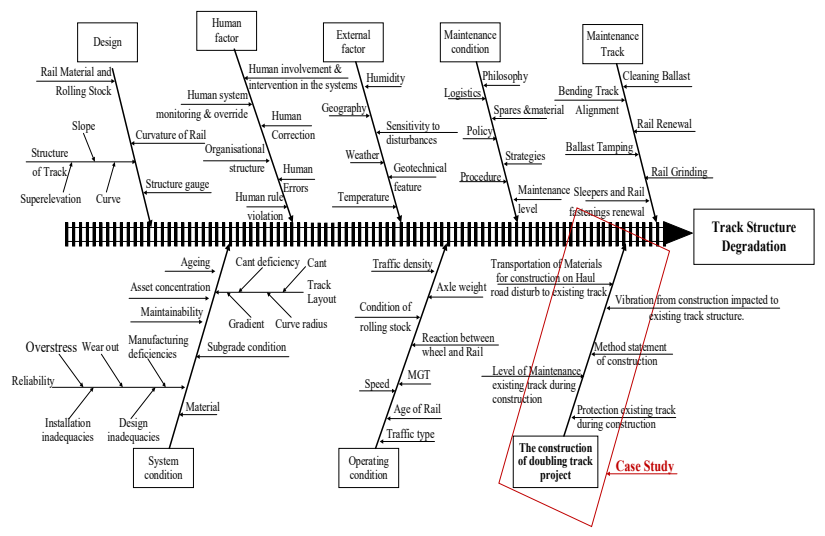

Fig. 4. Fishbone diagram showing factors influencing degradation.

Although track quality index (TQI) along the route has the same structural features such as rail, sleeper, ballast, and fastener installed at the same time and under same traffic, the degradation is significantly different that can be explained in Figure 7 and 8. The TQI values for each kilometer range under the same weight each year, but the TQI values are not equal because of natural factors. And other external factors are different, and the TQI value increases every year. 


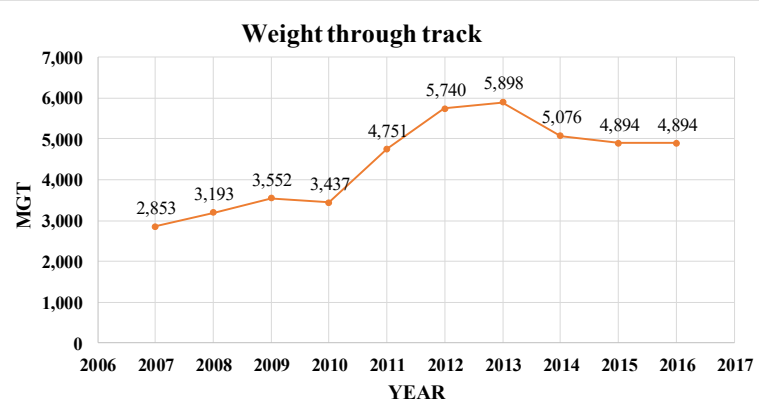

Fig. 5. Annual weight through track of NE line from year 2006-2016. [1]

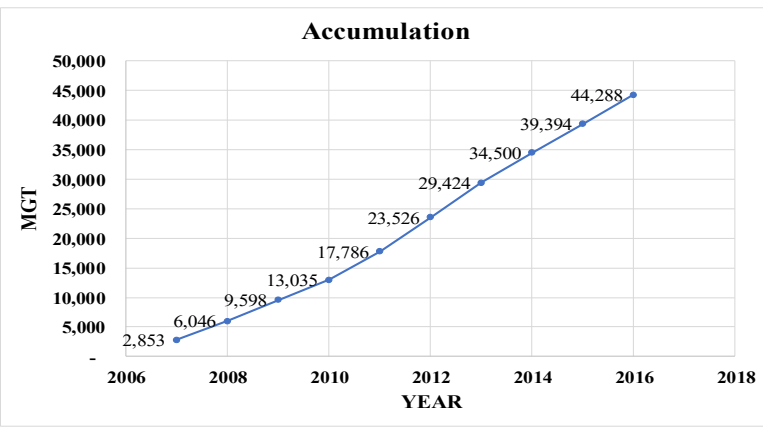

Fig. 6. Accumulated weight through track of NE line year 20062016. [1]

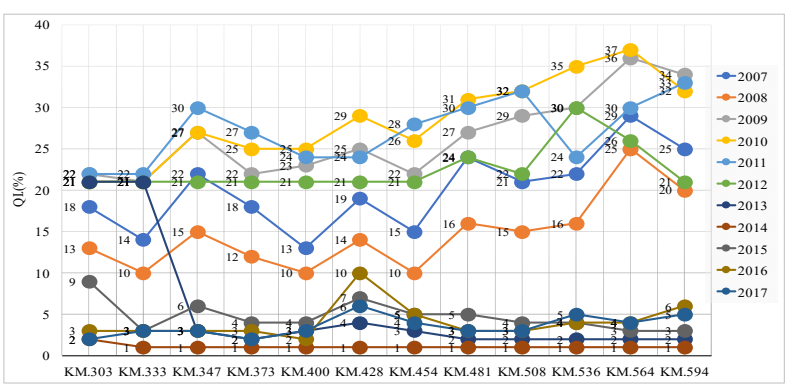

Fig. 7. TQI (\%) of NE line (KM.303-KM. 594). [SRT, 2017]

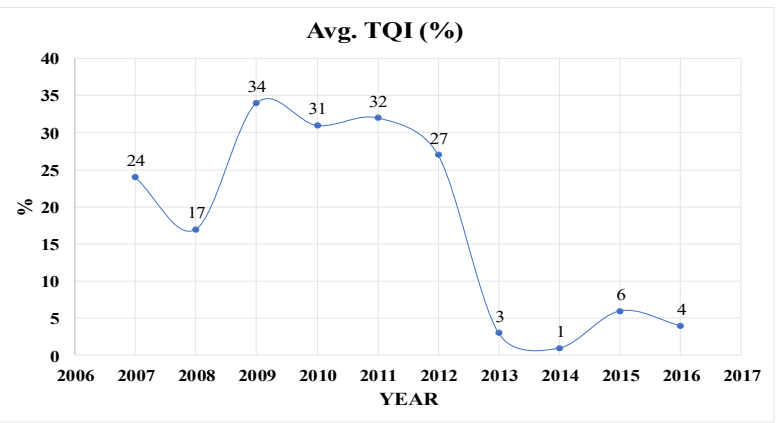

Fig. 8. Average TQI (\%) of NE line (KM. 303-KM. 594). [SRT, 2017]

Figure 7 and 8 shown high degraded track condition during 2007-2012 due to the increase of cumulative weight through track as shown in Figure 6. The existing track structure in 2007-2011 used BS7or on timber sleeper found by record TQI in 2009 was high up to 34 ("Not Fair" level which exceeded the standard of requirement on proper track condition prescribed by the SRT, so track rehabilitation was needed to be conducted for this line in 2012.For safety, timber sleeper was replaced by concrete one, and BS70R rail is also replaced by BS100A one to support more weight through track. After the rehabilitation, TQI was better 3\% - 6\% ("Very Good" level), and the service was regularly provided.

\section{Study Area}

In 2016, the government made a policy for improving rail transport to shorten transport time and increase efficiency of rail logistic to reduce environmental pollution as well as road accidents, and the policy was to induce more people to use rail transport service. Based on the policy, SRT was assigned to construct 187- kilometer double track parallel with existing track. According to the contract, the construction must be completely done within 2019. In the construction management, the level crossing is disused and replaced by 76 points of box underpass to prevent the train-car crashes that often occurred at a previous time.

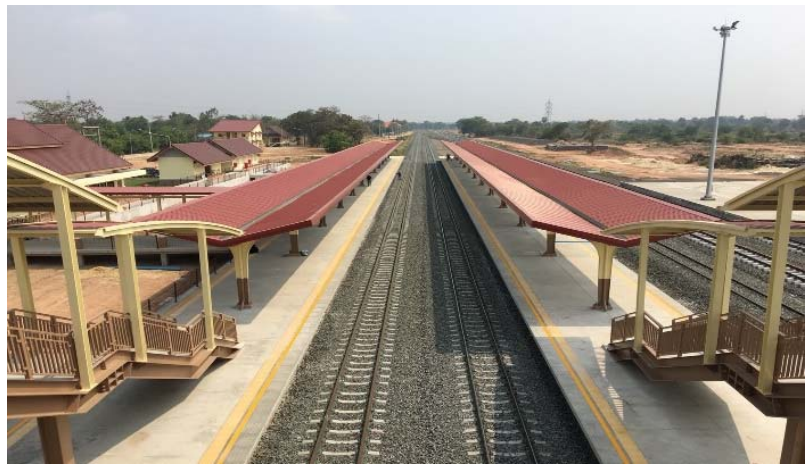

Fig. 9. Track doubling project. [SRT,2018]

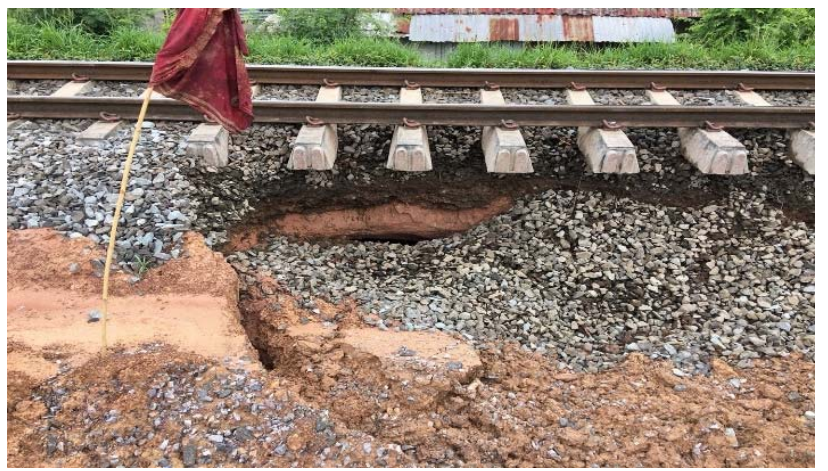

Fig. 10. Examples of factors influenced by substructure track collapse.

\section{Result}

Data collected by the EM120N track inspection Car has revealed that during 2016-2018, the existing structure of 187-kilometer Chira Junction - Khon Kaen has gotten higher TQI i.e. at "Very Good" level. During 2013-2016, 
TQI is $3 \%, 1 \%, 6 \%$, and $4 \%$, respectively while TQI during 2017-2018 is highly increased $15 \%$ and $25 \%$, respectively as shown in Figure 11.

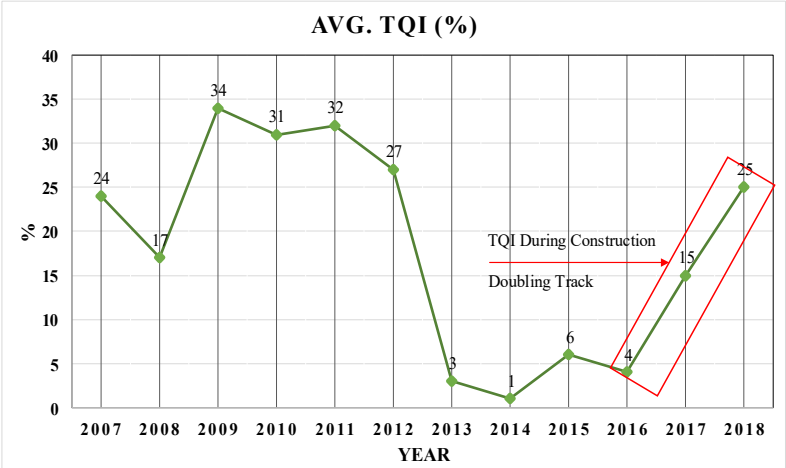

Fig. 11. TQI during 2017-2018 from EM 120N.

Table 2. Evaluation of the northeastern line 2007-2018.

\begin{tabular}{|c|c|c|c|l|}
\hline Year & $\begin{array}{c}\text { Annual } \\
\text { Accumula } \\
\text { ted } \\
\text { Weighing } \\
\text { (Ton) }\end{array}$ & $\begin{array}{c}\text { Avg. } \\
\text { TQI. } \\
\text { Value } \\
\mathbf{( \% )}\end{array}$ & $\begin{array}{c}\text { TQI } \\
\text { Compare } \\
\text { d with } \\
\text { SRT } \\
\text { Standard } \\
\text { s }\end{array}$ & Remark \\
\hline 2007 & $2,853,537$ & 24 & Fair & \\
\hline 2008 & $3,193,792$ & 17 & Good & \\
\hline 2009 & $3,552,172$ & 34 & Not Fair & \\
\hline 2010 & $3,437,941$ & 31 & Not Fair & \\
\hline 2011 & $4,751,526$ & 32 & Not Fair & \\
\hline 2012 & $5,740,382$ & 27 & Fair & \\
\hline 2013 & $5,898,270$ & 3 & $\begin{array}{c}\text { Very } \\
\text { Good }\end{array}$ & $\begin{array}{l}\text { Track } \\
\text { Rehabilitated }\end{array}$ \\
\hline 2014 & $5,076,001$ & 1 & $\begin{array}{c}\text { Very } \\
\text { Good }\end{array}$ & $\begin{array}{l}\text { Track } \\
\text { Rehabilitated }\end{array}$ \\
\hline 2015 & $\begin{array}{c}4,894,307 \\
\text { Very } \\
\text { Good }\end{array}$ & $\begin{array}{l}\text { Track } \\
\text { Rehabilitated }\end{array}$ \\
\hline 2016 & $2,853,537$ & 4 & $\begin{array}{c}\text { Very } \\
\text { Good }\end{array}$ & $\begin{array}{l}\text { Track } \\
\text { Rehabilitated }\end{array}$ \\
\hline 2017 & $\begin{array}{c}2,853,537 \\
\text { (N/A) }\end{array}$ & 15 & Good & $\begin{array}{l}\text { Doubling } \\
\text { Track }\end{array}$ \\
\hline 2018 & $2,853,537$ & 25 & Fair & $\begin{array}{l}\text { Doubling } \\
\text { Track }\end{array}$ \\
\hline N/A) & & & & \\
\hline
\end{tabular}

\section{Conclusion and future study}

The construction of doubling track project may have many parameters affecting the existing track according to TQI showing that the existing track structure has changed significantly. However, it is not over the point that can lead to the train derailment because SRT has strictly measured and controlled the operation of contractor. Thus, the study can predict the track degradation that it is caused by many factors from the construction of doubling track project. If we construct without any prevention of the existing track structure, and lack maintenance in time, it will be able to lead to the increase of degradation that exceeds a prescribed allowable value which produces transport insecurity of derailment. Thus, this study would like to recommend that degradation factors should be additionally studied after completed the track doubling project. Furthermore, when full service of double track is provided, it can possibly influence the degradation as well because weight through track of a train running on exiting track probably influences the degradation of a new track next to it. Benefits of the study can bring about to condition and behavior control of track infrastructure on the optimal areas in time that can improve reliability of service and safety. In addition, the factors that influence the existing track from the construction can be used for monitoring closely to maintenance in the future.

This study would not have been successful without the support of the Department of Civil Engineering, Faculty of Engineering, Khon Kaen University, Thailand. In addition, sincere gratitude goes to Maintenance Division Chief Khon Kaen Permanent Way Inspector of the State railway of Thailand (SRT), who is one part of this accomplishment supporting valuable data for the study.

\section{References}

1. Freight Service Department, State Railway of Thailand, Report on Weight and Train through the Railway 2007- 2016, the State Railway of Thailand, (2017)

2. Maintenance Department, Track Maintenance Manual, State Railway of Thailand, (1964)

3. Maintenance Department, Training Paper on Permanent Track, the State Railway of Thailand, (1994)

4. Stasha Jovanovic, Railway Track Quality Assessment and Related Decision Making, Delft University of Technology, Faculty of Civil Engineering \& Geosciences, Road and Railway Engineering Group, The Netherlands.

5. H. Guo, W. Wang, W. Guo, X. Jiang, and H. Bubb, "Reliability analysis of pedestrian safety crossing in urban traffic environment," Safety Science, vol. 50, no. 4, 968-973 (2012)

6. RITA, "Table 1 U.S. Domestic Freight Ton-Miles by Mode (2007).

7. National Bureau of Statistics of China, "China Statistical Yearbook 2012 [WWW]," (2012), http://www.stats.gov.cn/tjsj/ndsj/2012/indexeh .htm.

8. Grimes, G. A., and Barkan, C. P. L. (2006). "Costeffectiveness of railway infrastructure renewal maintenance." J. Transp. Eng., 132(8), 601608.

9. Bocciolone, M., Caprioli, A., Cigada, A., and Collina, A. (2007). "A measurement system for quick rail inspection and effective track maintenance strategy." Mech. Syst. Sig. Process., 21(3), 1242-1254. 